\title{
Role of P\&I Insurance in Implementing Amendments to Maritime Labour Convention 2014
}

\section{Ranka Petrinovića, Ivana Lovrića, Trpimir Perkušićb}

Maritime Labour Convention (MLC), 2006 stipulates mandatory financial security for repatriation costs (Standard A 2.5), and contractual compensations related to death or longterm disability of seafarers due to an occupational injury, illness or hazard (Standard A 4.2) that is to be provided by the shipowner. However, financial security system set in the MLC was prescribed very broadly and insufficiently precise and, therefore, it opened a number of questions and doubts. Among others, the following questions are particularly interesting: what the legal nature of the $M L C$ financial security is; from the insurance standpoint, whether this is life or accident insurance, or it is liability insurance; who has an insurable interest and what the nature of that interest is; which document proves fulfilment of $M L C$ requirements. Due to the necessity of improving financial security provisions, in 2014 Amendments to the MLC were adopted that came into force in January 2017. Although the $M L C$ does not explicitly prescribe a system of compulsory insurance, with the third injured party the right to a direct claim (actio directa) towards the liability insurer, marine insurance given its characteristic, appeared as a very suitable method of fulfilling $M L C$ requirements - especially P\&l insurance. All the clubs within the International Group of P\&I Clubs have agreed to assist their members (shipowners) in complying with these additional financial security requirements under the Amendments to the MLC and issue MLC Certificates to their members. MLC Certificates refer to the MLC Extension Clause, 2016 and thus subject the insurance to conditions and limitations in the said clause. MLC Extension Clause provisions will be added to clubs $P \& I$ Rules which form the standard $P \& I$ cover.

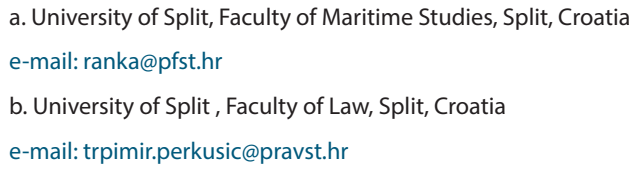

This work is licensed under (cc) BY

\section{KEY WORDS}

Maritime Labour Convention, 2006.

$\sim$ Amendments of 2014 to the MLC

$\sim$ Repatriation

$\sim$ Abandoned seafarers

$\sim$ Shipowners contractual liability

$\sim$ Financial security

$\sim$ P\&l Clubs

$\sim$ MLC Extension Clause

$\sim$ Regulations on the implementation of the Maritime Labour Convention, 2006.

\section{INTRODUCTION}

Seafarer labour relations represent specificum among working relations in general. International Labour Organization (ILO) adopted a number of conventions and recommendations on the regulation of labour relations for seafarers. A big step has been made with the adoption of a single, coherent instrument in the form of the Maritime Labour Convention, 2006. ${ }^{1}$ MLC embodies all relevant labour relations standards from previous international maritime labour conventions, with fundamental principles on labour relations in general found in other international labour conventions.

MLC was adopted at the 94th session of the ILO, held in Geneva, in February 2006, as a result of the work of Special Tripartite Committee comprised of government representatives, seafarer syndicate and shipowner representatives in order to further improve working and living conditions, social and other rights of seafarers. MLC entered into force in August 2013.

MLC significance, among other things, is the fact that it prescribes a system of protection of seafarers through the

1. Law on ratification of the Maritime Labour Convention (Zakon o potvrđivanju Konvencije o radu pomoraca), Narodne novine, International Agreements No. $11 / 09$. 
institution of financial security, which provides seafarers with an efficient way of exercising their rights. MLC stipulates mandatory financial security for repatriation costs ${ }^{2}$ (Standard A 2.5), and contractual compensations related to death or long-term disability of seafarers due to an occupational injury, illness or hazard (Standard A 4.2) that is to be provided by the shipowner. ${ }^{3}$

Due to broad and insufficiently precise provisions on financial security, in 2014 Amendments to the MLC were adopted that came into force in January 2017. With the Amendments' entry into force, for the first time in maritime history the position of abandoned seafarers and their financial security are settled through mandatory international legislation. ${ }^{4}$

\section{MARITIME LABOUR CONVENTION, 2006}

\subsection{About MLC}

MLC consolidated and modernized the standards of 37 conventions and 31 recommendations, 68 in total that have been adopted since the year 1920 under the aegis of the ILO. In relation to the previous ILO conventions, the $M L C$ enables the application of prescribed standards more effectively by stipulating obligations to the $M L C$ state parties and port state inspections and not by making new, different requirements.

MLC Convention is structured according to the practice used by the IMO for their instruments. Therefore, the binding norms and recommendations are integrated into a single act. $M L C$ consists of sixteen articles containing general provisions as well as the Regulations and the Code. Fundamental rights and principles as well as the MLC implementation and enforcement responsibilities for member states are given by the Articles and Regulations, while the Code contains details regarding the application of Regulations.

The Code consists of five Titles in which specific provisions are grouped by standard: Minimum requirements for seafarers to work on a ship, Conditions of employment, Accommodation, recreational facilities, food and catering; Health protection, medical care, welfare and social security protection and Compliance and

2. The term repatriation implies shipowners' obligation to ensure a seafarer's return to his place of residence if during, or after the termination of his service on board, the seafarer was asked to leave the ship in some port which differs from the port of his boarding the ship. Shipowner will have to fulfill this obligation only if during, or after the termination of seafarer's employment agreement, seafarer was asked to leave the ship in a port other than the port of his boarding.

3. According to MLC, shipowner means the owner of the ship or another organization, or a person such as the manager, agent or bareboat charterer, who has assumed the responsibility for the operation of the ship from the owner and who, on assuming such responsibility, has agreed to take over the duties and responsibilities imposed on shipowners in accordance with this Convention, regardless of whether any other organization or persons fulfill some of the duties or responsibilities on behalf of the shipowner.

4. Petrinović, R., Lovrić,l. (2015: p. 163) enforcement. For each Title, there are general Standards, which are further specified in mandatory Regulations (part A of the Code) as well as Guidelines (part B of the Code) which contain recommendations for member states when implementing the $M L C$ provisions into their national legislation. Regulations should in principle be implemented fully, while states are free to have different implementation measures from those suggested in the Guidelines.

Each member state has to ensure that ships flying its flag have Maritime Labour Certificate and Declaration of Maritime Labour Compliance. These certificates will be issued by the flag state of the ship as evidence of compliance with the MLC. Member state is required to exercise control over ships that fly its flag. Furthermore, ship subjected to the $M L C$, if in a port in $M L C$ member state, may be inspected by the port state authority to determine its compliance with the MLC. The port state authority has the right of detaining the ship if the ship does not have $M L C$ Certificates, and the conditions on board are not in accordance with $M L C$ provisions. Port state inspections apply to all vessels over 500 gross tons, whether or not their country has ratified the Convention.

\subsection{Amendments to MLC, 2014}

The 2014 Amendments to the Maritime Labour Convention, 2006 (hereinafter also referred to as the MLC Amendments or the Amendments) entered into force on 18 January, 2017. The MLC Amendments relate to financial security of seafarers in cases of abandonment, and in the event of seafarers' death or long term disability due to an operational injury, illness or hazard.

Standard A 2.5.2 established requirements which will enable providing a quick and efficient system of financial security to help the seafarers in the event of their abandonment. A seafarer will be deemed to have been abandoned where, in violation of the requirements of the MLC Convention or the terms of the seafarers' employment agreement, the shipowner fails to cover seafarers' repatriation costs, or leaves the seafarer without the necessary maintenance and support, ${ }^{5}$ or in some other way severs his ties with the seafarer, including failure to pay the contractual wages for a period of at least two months. ${ }^{6}$

Each state party has to ensure that ships flying its flag have met the financial security requirements in Standard A 2.5.2 of $M L C$. Financial security system can be in the form of a social security scheme or insurance, national fund, or some other similar arrangements. The final form will be determined by the state party after consulting the shipowners and seafarers'

5. According to the Amendments to the MLC, Standard A 2.5.2, p. 5: Necessary maintenance and support of seafarers shall include: adequate food, accommodation, drinking water supplies, essential fuel for survival on board the ship and necessary medical care.

6. Ibidem, p. 2 
associations. Financial security system has to provide every abandoned seafarer on a member states' ships, a direct access, sufficient coverage, and quick financial assistance. ${ }^{7}$ The financial assistance will be granted promptly to the seafarer upon his, or his representative's making request, in which the justification of said entitlement must be explained. ${ }^{8}$

MLC, 2006 already contained a provision under which the shipowner had to provide financial security to assure compensation for contractual claims as set out in national law, seafarer's employment agreement or collective agreement. ${ }^{9}$ Amendments to the MLC added a new provision which defines minimum requirements for these contractual compensations related to seafarers' death or long-term disability. ${ }^{10}$

According to the MLC Amendments, each state party ship that is flying its flag must carry on board a certificate or other document of financial security for repatriation costs and claims relating to death or long-term disability of seafarers, issued by the financial security provider. Certificates' copies have to be posted in a conspicuous place on board from where are available for seafarers to see. ${ }^{11}$

With the Amendments' entry into force, for the first time in maritime history the position of abandoned seafarers and their financial security will be settled through mandatory international legislation.

\subsection{Amendments to Standard 2.5 - Repatriation}

Repatriation is a way of solving specific problems that a seaman is faced with in case of abandonment, through rapid and efficient system of financial security. Shipowners need to implement financial security for the repatriation costs of seafarers. The financial security system has to provide any abandoned seafarer with a direct access (actio directa) towards the financial security provider and urgent financial assistance, sufficient enough to cover the basic needs, repatriation, and other justified costs, and with up to 4 months of outstanding wages and other entitlements which the shipowner owes the

7. Ibidem, p. 3 - 4 .

8. Ibidem, p. 8. Standard A 2.5.2, p. 9 says: The financial security system has to be sufficient to cover: up to four months of outstanding wages and other entitlements due from the shipowner to the seafarer under their employment agreement, relevant collective bargaining agreement or national law of the flag state; all expenses reasonably incurred by the seafarer, including the cost of repatriation and the seafarer's essential needs, as: food, clothing, accommodation, drinking water, essential fuel for survival on board the ship, medical care and any other reasonable costs or charges from the act or omission constituting the abandonment until the seafarer's arrival at home.

9. MLC, Standard A 4.2, p. 16 .

10. Amendments to the MLC, Standard A 4.2.2 - Treatment of contractual claims, p. 1: The term "contractual claim" means any claim which relates to death or long-term disability of seafarers due to an occupational injury, illness or hazard.

11. Ibidem, Standard 2.5.2, p. 6 and Standard A 4.2, p. 11. seafarer under the employment agreement, relevant collective agreement, or national law of the flag state. ${ }^{12}$

Financial assistance should be sufficient for the coverage of the seafarer's living costs, his essential needs from the day of the abandonment until his arrival home, including: food and water, clothing, accommodation, fuel for survival on board the ship, medical care and any other reasonable costs. ${ }^{13}$

Repatriation costs cover all reasonable costs or charges arising from the seafarer's abandonment including medical care, food, and accommodation from the time of leaving the ship until arriving home, and the seafarer's and his personal belongings' transport home, normally by air. ${ }^{14}$

If certain aspects of the seafarer's or his representatives' request need to be verified, it should not prevent the seafarer from immediately receiving requested financial assistance in a part which is recognized as justified. ${ }^{15}$

The MLC state parties require that ships flying its flag, carry on board a certificate or some other form of document, issued by the financial security provider, as evidence of placing the financial security for seafarers' repatriation under the $M L C$ Standard A2.5. Certificate copy has to be posted on board the vessel in a conspicuous place for seafarers to see. ${ }^{16}$

According to Appendix A2-I, the certificate or other documentary evidence has to include the following information: ships name, port of registry, call sign and IMO number, then the name and address of the financial security provider, contacts for handling seafarers' requests, name of the shipowner, period of the financial security validity and an attestation from the financial security provider that the financial security meets the requirements of the MLC Standard A 2.5.2. ${ }^{17}$ Certificate has to be written in English or accompanied by an English translation. ${ }^{18}$

\subsection{Amendments to Standard 4.2 - Shipowners' Liability}

Amendments to the MLC stipulate a new provision to Standard A 4.2.1 Shipowners' liability which defines minimum requirements for contractual compensations. The term contractual claim means any seafarers' claim related to death or long-term disability due to an occupational injury, illness or hazard as set out in the national law, seafarer's employment agreement or collective agreement. ${ }^{19}$

\footnotetext{
12.. Amendments to the MLC, Standard A 2.5.2, p. 4 and 9 .

13. Ibidem, Standard A 2.5.2, p. 9 (c).

14. Ibidem, Standard A 2.5.2, p. 10.

15. Ibidem, Guideline B 2.5.3 - Financial security, p. 1.

16. Ibidem, Standard A 2.5.2, p. 6.

17. Ibidem, Appendix A 2-I - Evidence of financial security under Regulation 2.5, paragraph 2.

18. Ibidem, Standard A 2.5.2, p. 7.

19. Ibidem, Standard A 4.2.1 - Shipowners' liability, p. 8. For the definition of the term contractual claim, see Standard A 4.2.2 - Treatment of contractual claims, p. 1.
} 
The minimum requirements set in the new paragraph 8 of Standard A 4.2.1 are as follows: the claim for contractual compensation may be brought directly by the seafarer, his representative, next of kin, or his designated beneficiary. There can be no pressure to accept a payment which is less than the contractual amount. The contractual compensation will be paid in full and without delay, unless the nature of the seafarer's long-term disability makes it difficult to assess the full entitled compensation, than an interim payment or payments shall be made in order to avoid excessive difficulty to the seafarer. The seafarer will receive the payment without prejudice to his other legal rights, but the payment may be offset by the shipowner against any other seafarer's claims against the shipowner that the seafarer placed for the same incident.

Certificate or other document issued by the financial security provider will be used as evidence that financial security is in place. A copy of it has to be posted on board member state ships from where it is available for seafarers to see. The certificate or other documentary evidence of financial security has to be written in English, or accompanied by an English translation, and has to contain information required in Appendix A 4- ${ }^{20}$ : ship's name, port of registry, call sign and IMO number, then the name and address of the financial security provider, contacts for handling seafarer's requests, name of the shipowner, period of the financial security validity, and an attestation from the financial security provider that the financial security meets the requirements of Standard A 4.2.1.21

\subsection{Declaration of Maritime Labour Compliance}

Declaration of Maritime Labour Compliance will be of two parts - Part I and Part II. Declaration of Maritime Labour Compliance - Part I will be issued by the competent authority ${ }^{22}$ and must be attached to the ship's Maritime Labour Certificate. Part I lists national requirements that embody the $M L C$ provisions and confirm that the ship named in the Declaration is maintained in accordance with the Convention. Declaration of Maritime Labour Compliance - Part II lists measures adopted in order to ensure compliance, between inspections, with the requirements listed in Part l.

Declaration of Maritime Labour Compliance (Part I and Part II) issued from 18 January, 2017 will have to contain both standards: - $\quad$ Financial security for repatriation (Regulation 2.5),

20. Ibidem, Appendix A 4-I - Evidence of financial security under Regulation 4.2

21. Ibidem, Standard A 4.2.1, p. 11 and 14.

22. Competent authority is defined in Article II, p. 1 (a) of the MLC under which it means the minister, government department or other authority that has the power of issuing and enforcing regulations that will have the force of law.
- Financial security relating to shipowner's liability (Regulation 4.2).

\subsection{MLC Certificates}

From 18 January, 2017 when the MLC Amendments came into force, the ships that are subject to the $M L C$ will be required to display certificates issued by an insurer or other financial security provider, confirming that insurance or other financial security is in place for liabilities in respect of:

outstanding wages and repatriation of seafarers together with incidental costs and expenses in accordance with $M L C$ Regulation 2.5, Standard A 2.5.2 and Guideline B 2.5, and - compensation for death or long-term disability in accordance with Regulation 4.2, Standard A 4.2 and Guideline B 4.2.

Certificate copies have to be posted on board all MLC member state ships and on board ships that will be calling ports situated in MLC member states. ${ }^{23}$

\subsection{Implementation of the MLC in Croatian Legislation}

$M L C$ has left the national legislations to regulate the working and social position of seafarers in the spirit of their national legal and political system, and thereby meet the highest standards set by the Convention. ${ }^{24}$ The Republic of Croatia ratified the MLC in February 2010, and harmonized its national legislation with its provisions. The Croatian legislator implemented the $M L C$ provisions in the Croatian Maritime Code through amendments to the Pomorski zakonik from 2011 (hereinafter referred to as $P Z$, 2011). ${ }^{25}$ Provisions which enable the implementation of $M L C$ Regulations and Standards relating to repatriation (Standard 2.5) were incorporated to $P Z, 2011$. In doing so, article $139 a^{26}$

23. International Labour Organization formed MLC database which contains ratification and implementation information of Maritime Labour Convention in all countries that have adopted the MLC Convention. MLC database can be found on ILO website, online at http://www.ilo.org/global/standards/maritime-labourconvention/database-ratification-implementation/lang--en/index.htm, [accessed 25 February 2017.].

24. Petrinović, R., Lovrić,l. ibidem, p. 151.

25. Amendments to PZ (Zakon o izmjenama i dopunama Pomorskog zakonika), Narodne novine No. 6/11.

26. Ibidem, art 139 a says:

(1) Shipowner will provide insurance or other financial security to cover repatriation costs for crew members.

(2) Shipowner will ensure that relevant legislative provisions concerning the right of crew members to repatriation costs are available to crew members on all ships.

(3) Relevant legislative provisions under paragraph 2 of this Article shall be made available in speaking, working language of the ship and in English. 
and $1016 \mathrm{c}$ are new, and were added to the $P Z$, and the existing articles $138^{27}$ and $139^{28}$ were amended.

According to $P Z$, the shipowner will be liable for damages related to death, personal injury, or deterioration of health of seafarers incurred while working or in connection with working on board, if the damage can be attributed to the shipowner's actions. The shipowner will not be liable for such damages if he can prove that he is not culpable, and the damage was caused without his fault. ${ }^{29}$ Legislative solutions on the shipowner's liability for the death and personal injury of seafarers are based on presumed guilt (as a general principle), or on objective liability (in special $\operatorname{cases}^{30}$ ). Furthermore, liability insurance provisions in the $P Z$, stipulate seafarer's right as a third party, to a direct claim towards the insurance provider for the claims related to seafarer's death, personal injury or deterioration of health. ${ }^{31}$

According to the amendments to $P Z$ from $2013^{32}$ Minister of maritime affairs was obligated to adopt a regulation which would determine in detail how $M L C$ provisions are to be implemented in the Croatian legislation, and thereby remove all doubts incurred by the lack of precision of MLC provisions on how financial security should be provided.

Pursuant to art 125, p. 5 of $P Z$, the Minister issued on 13 December, 2016 Regulations on the implementation of the Maritime Labour Convention, 2006 (hereinafter also referred to as Regulations on the implementation of the MLC or

27. Ibidem, in art 138 after p. 1, p. 2 and p. 3 are added:

(2) Repatriation costs, referred to in paragraph 1 of this Article, shipowner may not collect from a crew member at the beginning of employment in the form of an advance, or from crew members entitled wages, except in a case of severe breach of the employment contract by the crew member.

(3) If the shipowner does not refund sums paid for crew member's repatriation under paragraph 1 of this Article, taking into account all applicable international standards, ships of said shipowner could be detained.

28. Ibidem, art 139, p. 3 is amended as follows: Crew members repatriation costs include accommodation, transport costs, wages and other entitlements from the moment of leaving the ship until the seafarers' arrival home at the place of his residence, including necessary medical care till the seafarer's medically fit for the return voyage home.

29. Pomorski zakonik, art 145, p. 1. Liability is joint for these damages and include the shipowner, manager, transport operator and the company.

30. Ibidem, art 145, p. 2 (damage caused by dangerous materials or activities and damage to the crew member incurred while working or in connection with working on board due to absence of safe working conditions).

31. Pomorski zakonik, art 743, p. 2 says: Only when specifically provided, as in the case of death, personal injury and crew members' deterioration of health, the damaged party may place an insurer a direct claim for compensation due to damages sustained by the event for which the insured is responsible, up to the amount of insurers' liability. In marine insurance, a direct action is provided only in two cases: compulsory insurance and claims of crew members due to death, personal injury or illness. For more see: Petrinović, R., Lovrić, I., (2015: p. 152).

32. Amendments to the PZ (Zakon o izmjenama i dopunama Pomorskog zakonika), Narodne novine, No. 56/13, art 125, p. 5.
Regulations). ${ }^{33}$ Regulations entered into force on 18 January, 2017, simultaneously with the Amendments to the MLC, and its provisions are in compliance with MLC Amendments provisions.

Regulations in detail regulate financial security for seafarers' repatriation costs and the contractual in accordance with the Amendments to the MLC, 2014. Contractual claim means any seafarer's claim related to the death or long-term disability due to an occupational injury, illness or hazard as set out in the national law, the seafarer's employment agreement or collective agreement. ${ }^{34}$ According to the Regulations, the shipowner is obligated to provide financial security and ensure that the document ${ }^{35}$ issued by the insurance or other financial security provider, is on board the ship, as evidence of having financial security in place. Such document should be placed in a prominent and accessible place for seafarers on board and contain the necessary information about the ship, shipowner and financial security provider as the document's period of validity. This document of financial security also has to contain an attestation from the financial security provider, that the financial security meets the requirements of the MLC Standard A 2.5.2. and Standard A 4.2.2. ${ }^{37}$

Insurance or other financial security set in place for contractual claims and repatriation of a seafarer should not cease before the end of the period of validity of the financial security unless the financial security provider has given prior notification of at least 30 days to the Ministry of the Sea, Transport and Infrastructure. ${ }^{38}$ If a shipowner's financial security is to be cancelled or terminated, the shipowner has to notify the seafarers on board the ship of such cancellation as soon as possible. ${ }^{39}$

\section{THE ROLE OF P\&I CLUBS IN MLC IMPLEMENTATION}

\subsection{International Group of Protection \& Indemnity Clubs and Maritime Labour Convention}

International Group of Protection \& Indemnity Clubs (hereinafter also referred to as the Group, or $/ G$ ) is an unincorporated association of 13 principal underwriting

33. Regulations on the implementation of the MLC, 2006 (Pravilnik o primjeni Konvencije o radu pomoraca, 2006), Narodne novine, No. 122/2016.

34. Ibidem, art 7, p. 1 and p. 2. The same definition of the term "contractual claim" is in Amendments to the MLC, Standard A 4.2.2 p. 1.

35. The document has to be written in English or accompanied by an English translation.

36. Regulations to the MLC, ibidem, art 5 .

37. Ibidem, art 8.

38. Ministry of the Sea, Transport and Infrastructure (Croatian: Ministarstvo mora, prometa i infrastrukture) is the competent authority for MLC implementation in Croatia.

39. Ibidem, art 9 . 
associations and their affiliated associations and reinsured entity. ${ }^{40}$ The Group is based at Peek House in London. Each club within the Group is an independent, non-profit mutual insurance association that provides cover for its shipowner and charterer members against third party liabilities relating to the use and operation of ships. Each club is controlled by its members through a board of directors. Together, these 13 clubs provide liability cover (protection and indemnity) for approximately $90 \%$ of the world's gross tonnage. ${ }^{41}$

$P \& I$ clubs provide insurance for broader, indeterminate risks which marine insurers usually do not cover, or are reluctant to insure, such as third party risks. So, clubs provide cover for a wide range of liabilities, including personal injury to crew, passengers and others on board, cargo loss and damage, oil pollution, shipowner's liability after a collision, wreck removal and dock damage, and war risks. To members, clubs offer services and provide help with the legal issues, loss prevention and claims. ${ }^{42}$

On the issue of $M L C$ implementation and certification, clubs within the Group cooperate and form unified decisions. In doing so, all clubs within the Group issue uniform Circulars of the same title and content. By way of Circulars, all members are informed on current proceedings and reached decisions. These Circulars give members guidelines on how to address certain issues. So, Circulars bear a very important function in dealings of $P \& I$ Clubs as they standardize the business practice in general and in our case, in MLC implementation. So, every club has issued several Circulars on the MLC, Amendments to $M L C$ and the certification process. The Group did not act secluded, but has consulted a number of key states in order to establish a common approach in providing financial security according to the $M L C$, amongst 80 states which have ratified the Convention by now.

As already pointed out, the MLC Amendments aim at ensuring the financial security of seafarers by implementing new provisions on the protection of abandoned seafarers and the protection of seafarers injured in accidents at work.

All Clubs in the Group have agreed to provide their members with MLC certification. The club will issue its member two sets of MLC Certificates, for repatriation costs and contractual claims. The Certificates contain a provision which subjects the insurance to conditions and limitations in Maritime Labour Convention Extension Clause, 2016 (hereinafter also referred as the MLC Extension Clause, 2016). MLC Extension Clause will be considered

40. Principal underwriting associations in the International Group of Protection \& Indemnity Clubs are: American Steamship Owners; Skuld; Gard; Britannia; Japan Ship Owners'; The Swedish Club; UK P\&l; West of England; London Steam-Ship Owners'; North of England; Shipowners' P\&l; Standard Club; Steamship P\&l; Sveriges Ångfartygs Assurans Förening, For more on the International Group on IG P\&I website, online at: http://www.igpandi.org/, [accessed 14 February 2017.].

41. Ibid.

42. More on the P\&l Clubs online at: https://en.wikipedia.org/wiki/Protection and_indemnity_insurance, [accessed 13 February 2017.]. as an addition to the clubs $P \& I$ Rules that form the standard $P \& I$ cover. ${ }^{43}$

Should the MLC event occur, the club will directly indemnify the seafarer. The club has the right of indemnity from the member in respect of entitlements following abandonment, and on the basis that these new MLC liabilities do not fall within the Group's existing pooling arrangements. ${ }^{44}$

The Group plans to establish additional reinsurance for liabilities arising under the MLC Extension Clause and those falling outside its scope of coverage. All Group clubs have agreed to participate in this separate reinsurance arrangement that will address aggregation of risk in the event that a club becomes liable for members' financial default that resulted in seafarer abandonment. Reinsurance scheme will be placed in the near future, and should be enough for all members. But, there are indications that it would not be at the level capable to manage claims coming from a small number of fleets with exceptionally high crew numbers. ${ }^{45}$

\subsection{Application Process for MLC Certificates at P\&I Club}

Every IG club has issued a similar announcement informing their members on the application process for MLC Certificates. The application process is basically the same in every Group's club. Club members (shipowners) using the Application Form, apply for Certificates on a basis of per vessel or per fleet. ${ }^{46}$ After

43. Each P\&I Club in the IG announced in June 2016 Circular - Update on the Maritime Labour Convention (MLC). All Circulars are of the same content which says that the P\&I Club will provide its member the financial security under the MLC by issuing MLC Certificates. More on The Shipowners Club website, online at: https://www.shipownersclub.com/publications/update-on-the-maritimelabour-convention/, [accessed 22 December 2016.].

44. Clubs within the IG agreed on the joint coverage of high risk claims. Pooling Agreement is in the joint interest of all clubs, as it reduces their risk exposure and provides a safer way of business, regardless of the fact that in ordinary line of business these clubs are competitors.

The Pooling Agreement explicitly defines which risks will the clubs jointly bear and which risks are excluded from coverage. The Pooling Agreement also defines in which ratio individual club will participate in covering the damage, arising from the realization of risk covered by the agreement. According to the terms of the Pooling Agreement, clubs have to share all qualifying claims in excess of $\$ 10$ million. While the Group gives guidelines, coordinates and regulates the claims which are to be pooled. Also, if needed, the Group placed a reinsurance programme for support to claims sharing agreement. More on IG website, online at: http://www.igpandi.org/group-agreements, [accessed 22 January 2017.].

45. See Circular 16/16: Maritime Labour Convention, 2006 as Amended (MLC) on The Shipowners' Club web site, online at: https://www.shipownersclub.com/ publications/maritime-labour-convention-2006-as-amended-mlc-financialsecurity-requirements/, [accessed 22 February 2017.].

46. See the Application Process for MLC Certificates on the UK P\&I Club website, online at https://www.ukpandi.com/knowledge-publications/article/ application-process-for-mlc-certificates-136479/, [accessed 22 February 2017.]. 
submitting the application to their usual underwriter in the club, the club will issue its member MLC Certificates. By returning the signed application, the member agrees to the undertakings contained in it, as well as the terms of the MLC Extension Clause, 2016.

From 18 January, 2017 when the MLC Amendments came into force, certificate copies have to be posted in a conspicuous place on board the ship, available to seafarers. MLC Certificates are provided by the $P \& I$ Club and there is no need to apply for state-issued Certificates. However, some flag states may require shipowners on their register to supply copies of MLC Certificates for their records, in which case shipowners are responsible for this process.

Clubs will keep records of issued Certificates to ships. These records will be available on the Club's website, thus providing flag states and port state authorities a reliable form of verification which ships have the needed financial security certification in place and which do not. ${ }^{47}$

$P \& I$ Club will issue its member two sets of Certificates:

- Certificate of insurance or other financial security in respect of shipowner's liability, as required under Regulation 4.2, Standard A 4.2, Paragraph 1 (b) of the Maritime Labour Convention 2006. as Amended, and

Certificate of insurance or other financial security in respect of seafarer repatriation costs and liabilities, as required under Regulation 2.5.2, Standard A 2.5.2 of the Maritime Labour Convention 2006. as Amended.

\subsection{MLC Extension Clause, 2016}

Some liabilities in MLC Certificates fall within the scope of standard $P \& I$ cover for crew, but some of them do not, as they are new additional financial security requirements brought by the Amendments to the MLC, 2014.

Liabilities in respect of compensation for death or long term disability, repatriation costs and wages after a shipwreck, form a part of standard cover in the P\&l Clubs Rules. However, there are other liabilities in MLC Certificates that are not normally covered by clubs $P \& I$ Rules. In particular, repatriation costs and wages arising from abandonment.

MLC Certificates contain a provision that names Regulations and Standards in the MLC, 2006 as Amended, to which the certificates apply. In this way, the certificates define their coverage. Furthermore, both MLC Certificates contain a provision which subjects their coverage to conditions and limitations in the MLC Extension Clause, 2016. According to MLC Extension Clause, the club will only pay the claims which fall within the scope of Regulations and Standards specified in MLC Certificates

47. Circular 16/16: Maritime Labour Convention, 2006 as Amended (MLC), ibidem. (paragraphs 1a, 1b). But, if such payments fall outside the scope of the standard cover, the members will be obliged to reimburse the club (MLC Extension Clause, paragraphs 2a, 2b).

The claims that fall outside the scope of $P \& I$ cover, neither will be part of pooling and reinsurance arrangements between the clubs in the Group. Nevertheless, the Group plans to establish reinsurance scheme for liabilities arising under the MLC Extension Clause. This additional reinsurance would also be for liabilities that fall outside its scope of coverage. ${ }^{48}$

According to paragraph $1(\mathrm{a}, \mathrm{b})$ of the MLC Extension Clause, the Association will pay on the member's behalf under the MLC as Amended, 2006 or domestic legislation of a state party implementing MLC:

Liabilities and accompanying costs and expenses in respect of outstanding wages and repatriation of a seafarer in accordance with Regulation 2.5, Standard A 2.5 and Guideline B 2.5,

Liabilities in respect of compensating a seafarer for death or long-term disability in accordance with Regulation 4.2, Standard A 4.2 and Guideline B 4.2.

If liabilities, costs or expenses payable under this MLC Extension Clause are also recoverable by any other separate insurance, social security scheme or fund, or any other similar arrangement, there will be no payment by this insurance to the extent that such claim is recoverable by that other insurance. In other words, this insurance will only pay the difference in compensation between the other insurance and this one (MLC Extension Clause, paragraph 3).

Members do not have to reimburse the Association for claims paid under paragraph 1 of the MLC Extension Clause if they are covered by the clubs' $P \& I$ Rules.

The member has to reimburse the Association for the claims paid under paragraph 1 of the MLC Extension Clause, but if the claim is covered by the club's $P \& I$ Rules, he will not have to reimburse the club. Therefore, the member shall reimburse the Association in full for the claims paid under paragraph 1(a) of the MLC Extension Clause, save to the extent that such claim is recoverable under Rule 2, Sections 2, 3, 4(A), or 6 of the club's P\&I Rules (MLC Extension Clause, paragraph 2(a). In other words, the member will not have to reimburse the Association for those claims that were paid under paragraph 1 of the MLC Extension Clause, but are covered by the club's Rules. Rule 2, Sections 2, 3, $4(A)$, or 6 in the $P \& I$ Rules regulate the cover of liabilities, costs or expenses for injury or death of a seafarer, illness and death of seafarers, cost of repatriation and replacement cost of a seafarer with another seafarer, seafarer compensation for loss of employment due to actual or derived total loss of the ship.

Similarly, the member shall reimburse the Association in full for claims paid under paragraph $1(\mathrm{~b})$ of the MLC Extension

48. Each P\&I Club has posted specimens of MLC Certificates on their web page. More on the certification process, $P \& I$ insurance and reinsurance of liabilities, ibidem. 
Clause, save to the extent that such claim is recoverable under Rule 2, Sections 2 or 3 of the clubs P\&I Rules (MLC Extension Clause, paragraph 2(b)). Liabilities, costs or expenses for injury or death of a seafarer, as well as illness and death of a seafarer are regulated by Rule 2, Sections 2, 3 in the P\&I Rules.

Liabilities, costs or expenses covered under paragraph 1 (a) and paragraph 1 (b) of MLC Extension Clause will be excluded from this cover if they contributed to, or were directly or indirectly caused by, or risen from:

any chemical, biological, bio-chemical or electromagnetic weapon,

the use or operation of any computer system, software programme, computer virus or any other electronic system with the intent of inflicting harm (MLC Extension Clause, paragraph 4(a, b)).

It wouldn't be of relevance if such liabilities, costs or expenses were incurred by, or caused by the neglect of the member or member's servants or agents.

War Risks are excluded from the Extension Clause cover and the insurance will terminate automatically if they happen. For the purposes of this insurance, war risks include the outbreak of war between the UK, USA, France, Russian Federation or People's Republic of China, and the requisition of the insured ship (MLC Extension Clause, paragraph 5(b)).

According to the paragraph 5(a) of the MLCExtension Clause, the Association may cancel this cover by giving the member 30 days' notice, due to the emergence of war risk.

Loss, damage, liability or expense arising from the requisition, or outbreak of war between the UK, USA, France, Russian Federation or People's Republic of China will be excluded from this cover (MLC Extension Clause, paragraph 5(c)).

Paragraph 6 in the MLC Extension Clause subjects this extension cover to the provisions of Rule $5(\mathrm{~F})$ and $5(\mathrm{~V})$ in the $P \& l$ Rules of a club. Rule $5(\mathrm{~F})$ excludes from the cover nuclear risks and Rule 5(V) excludes liabilities, costs or expenses which could expose the club to state sanctions, restrictions, or penalties.

According to paragraph 7, cover under the MLC Extension Clause shall cease 30 days after giving the notice of termination. Disputes arising from, or in connection with this insurance are to be resolved in accordance with Rule 40 of the $P \& I$ Rules that determines the disputes are to be settled in court or arbitration in England (MLC Extension Clause, paragraph 8).

\section{CONCLUSION}

In order for seafarers to exercise their rights under the MLC, seafarer's right to a direct claim towards the liability insurer is of utmost importance, particularly when it comes to abandoned seafarers who have tried to reimburse their claims from the shipowner, but unsuccessfully. The best way of complying with the provisions on mandatory financial security in case of abandoned seafarers, and seafarers' death or long-term inability incurred while working, is through $P \& I$ liability insurance. Nevertheless, as outlined in the MLC Convention, this does not exclude the possibility of placing other suitable forms of financial security such as bank guarantees, social security scheme, state funds, and others,

Owing to the fact that seafarer life is very specific and contains elements of common interest, the seafarer's right to life and physical integrity is especially protected. Hence, clubs' P\&I Rules determined that a third party (seafarer) has the right to a direct claim towards the club for compensation related to death or personal injury. In such a case, the club has no right to call on a pay to be paid clause. Also, liability insurance provisions in the Croatian Maritime Code (Pomorski zakonik), provided the right of a seafarer, as a third party, to a direct claim towards the maritime insurer for claims related to death, personal injury or impaired health. However, this applies only to physical damages occurred to seafarers. Other seafarers' rights could not be claimed directly from the insurer.

Clubs were explicitly opposed to covering the shipowners' liability in case of seafarers' abandonment. But, their reluctance changed significantly after the adoption of MLC Convention and especially MLC Amendments in 2014. Since the MLC comprehensively deals with seafarer rights, it became the perfect instrument to empower the provision on financial security for abandoned seafarers, which had previously existed only in nonbinding international law (IMO resolution A.930 (22)). Mandatory financial security required by the MLC Amendments also applies to repatriation in the event of seafarers' abandonment (Standard 2.5.2).

A seafarer will be deemed to have been abandoned where, in violation of $M L C$ provisions or the terms of the seafarers' employment agreement, the shipowner fails to cover seafarers' repatriation costs, or leaves the seafarers without necessary maintenance and support, or in some other way severs his ties with the seafarers, including the failure to pay contractual wages for a period of at least two months.

A number of ambiguities and the vagueness of $M L C$ financial security provisions have been limited in business practice, especially thanks to $P \& /$ Clubs which have demonstrated their inevitability when it comes to protecting the interests of shipowners and their seafarers.

International Group of Protection \& Indemnity Clubs is an unincorporated association of 13 independent, non-profit mutual insurance associations. Together, these 13 clubs within the Group provide liability cover (protection and indemnity) for approximately $90 \%$ of the world's ocean-going tonnage. The clubs within the Group jointly addressed the issue of $M L C$ implementation, and afterwards the Group consulted a number 
of key states in order to establish a common approach in providing financial security according to the $M L C$, amongst 80 states who have ratified the Convention by now.

All the clubs in the Group have agreed to provide their members with the $M L C$ certification which confirms that the $M L C$ financial security is in place. The club will issue its member two sets of MLC Certificates, for repatriation and contractual claims. Certificates contain a provision which subjects the insurance to conditions and limitations in the MLC Extension Clause, 2016. MLC Extension Clause will be considered as an addition to the clubs $P \& I$ Rules that form standard $P \& I$ cover. Should the $M L C$ event occur, the club will directly indemnify the seafarer.

The clubs will keep records of issued MLC Certificates to ships. These records will be available on the clubs' websites, thus providing the flag states and port state authorities with a reliable form of verification as to which ships have needed financial security certification in place and which have not.

\section{REFERENCES}

Application Process for MLC Certificates, available at: https://www.ukpandi.com/ knowledge-publications/article/application-process-for-mlc-certificates-136479/, [accessed 22 February 2017.].

Hazelwood, S. and Semark, D., (2010), P. \& I. Clubs, Law and Practice, London: Lloyd's List.
International Group of Protection \& Indemnity Clubs, home page, available at: http://www.igpandi.org/, [accessed 14 February 2017.].

Luttenberger, A., (2005), Pomorsko upravno pravo, Rijeka: Pomorski fakultet u Rijeci.

Lavelle, J., (2014), The Maritime Labour Convention 2006, Oxon: Informa Law from Routledge.

Odluka o proglašenju zakona o potvrđivanju Konvencije o radu pomoraca iz 2006. godine, (2009), Narodne novine, 2009(11).

Pavić, D., (2012), Pomorsko osiguranje - pravo i praksa, Split: Književni krug.

Petrinović, R. and Lovrić, I., (2015), Osiguranje pomoraca prema novoj Konvenciji o radu pomoraca, Poredbeno pomorsko pravo, 54(169), pp. 145 - 170.

Pomorski zakonik, Narodne novine, 2004(181), 2007(7), 2008(146), 2011(61), 2013(56), 2015(26)

Pravilnik o primjeni Konvencije o radu pomoraca iz 2006. godine, (2016), Narodne novine, 2016(122).

Protection and indemnity insurance, available at: https://en.wikipedia.org/wiki/ Protection_and_indemnity_insurance, [accessed 13 February 2017.].

Ratification and implementation information for the Maritime Labour Convention, (2006), available at: http://www.ilo.org/global/standards/maritime-labourconvention/database-ratification-implementation/lang--en/index.htm, [accessed 25 February 2017.].

Update on the Maritime Labour Convention (MLC), (2016), available at: https://www. shipownersclub.com/publications/update-on-the-maritime-labour-convention/, [accessed 22 December 2016.]. 